\begin{abstract}
"Mircea cel Batran" Naval Academy Scientific Bulletin, Volume XX - 2017 - Issue 2
The journal is indexed in: PROQUEST / DOAJ / Crossref / EBSCOhost/ INDEX COPERNICUS/ OAJI / DRJI /

JOURNAL INDEX I I2OR / SCIENCE LIBRARY INDEX / Google Scholar I Academic Keys / ROAD Open Access I

Academic Resources / Scientific Indexing Services I SCIPIOI JIFACTOR
\end{abstract}

\title{
METHODOLOGICAL ASPECTS ON THE DEVELOPMENT OF MOTOR SKILLS IN CHILDREN
}

\author{
Sanda TOMA-URICHIANU ${ }^{1}$ \\ ${ }^{1}$ Professor Ph.D., Ecological University, Bucharest, Romania, sandavtoma@yahoo.com
}

\begin{abstract}
To demonstrate that the development of physical skills in children is the basis of basic motor skills training, I have participated in a study on the adaptation of children to the swimming effort; the conclusion is that general physical training is one basic component of sports training. We followed a 16 children aged 7 to 10 years test subjects of a group of beginners from No. 1 Bucharest Sports Club during one year of training.

The selection criteria were the following: health status, training frequency, work discipline, motivation for movement, good school performance, and good relationship with parents.

Initial and final tests were established and the progress achieved was recorded. The end of the initiation and development period highlighted a number of 6 athletes prone to achieving peak performance in swimming. One of them proved to reach national quality performance.
\end{abstract}

Keywords: adaptation, multi skill training, effort capacity.

1. Introduction.

The human body has evolved through physical activity and still needs it to stay healthy. Throughout history, man's survival depended on hunting or feeding herds, searches which urged man to carry on prolonged and often tedious physical activity. The emergence of modern mechanics and technology during the last few decades have led to humans turning into less physically active individuals, even in poor health.

Children's recreational activities have changed over the past decades. While children used to spend much of their time playing outdoors, the emergence of television, computer games and the Internet made most children spend much of their free time in sedentary activities. Practicing physical activity for movement is important, even a landmark for youth mental and social health, and great efforts are being made around the world to "reintroduce" physical activity to all age groups.

One of the greatest challenges of the 21st century, caused by physical inactivity, is obesity in children, whose responsibility is for the whole society. Schools, kindergartens, universities, and the community in general are excellent organizations to help children improve their health-related lifestyle behaviors such as physical activity.

That's why practicing sport is important starting with the smallest age group children, which can train to performance athletes, if talented.

The adaptation of children to the training effort, in other words, their response to training stimuli is correlated with the critical growing-up process. For example, it is often thought that very young athletes are more sensitive to the positive effects of training during periods of rapid growth, that is, preadolescence.
Reference has been made in particular to the effects of regular training programs on the development of muscle strength and aerobic power. It also appears to be applicable to the effects of developing and learning motor skills.

The subjective sensitivity of learning depends on a variety of factors such as age, previous experience, level of learning or training, strength and aerobic power, and possible specific genetic variations. Because most of the nerve structures have almost reached adulthood, and most of the fundamental motion schemas are well structured, this period can be considered as optimal for learning and enhancing basic motor skills

2. Methodological aspects regarding the development of motor skills

Training of swimmers is a process not only of improving motor skills, and motor skills building, but training and advanced learning, as well. One of the basic components of sport training is physical training, which implies:

- Building fine motor skills;

- Mastering a wide variety of skills and abilities;

- Development of the morphological and functional body index, specific to each sport

For the state-of-the art sport training session, ensuring higher physical training index has become a basic condition for obtaining the necessary outcome efficiency, and at the same time, for the continuous increase of its performance level.

The complex field of physical training, as well as its importance in the training of athletes, determined the variation of this component as:

- $\quad$ Multi skill physical training;

- $\quad$ Specific physical training. 
"Mircea cel Batran" Naval Academy Scientific Bulletin, Volume XX - 2017 - Issue 2

The journal is indexed in: PROQUEST / DOAJ / Crossref / EBSCOhost/ INDEX COPERNICUS/ OAJI / DRJI /

JOURNAL INDEX I I2OR / SCIENCE LIBRARY INDEX / Google Scholar I Academic Keys / ROAD Open Access I Academic Resources / Scientific Indexing Services I SCIPIOI JIFACTOR

For the effectiveness of sports training, it is essential to maintain an optimum balance between the child's performance and the specific performance requirements.

3. The values of physical fitness factors and the proficiency tests

Within a study in the field of sportive motor

several areas: of force, flexibility, balance, coordination and endurance. He proposes to measure the basic physical fitness or value, "Basic fitness", nine factors assessed by the tests as following: skills, Fleischman, E., (1964) distinguishes

Table 1. Factors appreciated by "Basic Fitness" (after Fleischman, E., 1964)

\begin{tabular}{|l|l|l|}
\hline FACTORS & DESCRIPTION & TEST \\
\hline 1. Explosive force & $\begin{array}{l}\text { The ability to prove great energy in a very } \\
\text { short time }\end{array}$ & Throwing the ball \\
\hline 2. Static flexibility & Amplitude joint & $\begin{array}{l}\text { The amplitude of the } \\
\text { bending of the trunk before }\end{array}$ \\
\hline 3.Dinamyc flexibility & $\begin{array}{l}\text { The ability to perform rapid movements } \\
\text { involving several muscle flexibility }\end{array}$ & Flexie - rotation \\
\hline 4. Static force & Maximum force proven short time & Manual dynamometer \\
\hline $\begin{array}{l}\text { 5. Dynamic force } \\
\text { 6. Trunk strength, } \\
\text { coordination }\end{array}$ & $\begin{array}{l}\text { Factor involves repeated action of the } \\
\text { muscular }\end{array}$ & Traction fixed bar \\
\hline 7. Coordination & $\begin{array}{l}\text { The ability to coordinate many of the body } \\
\text { segment }\end{array}$ & Jumping rope \\
\hline 8. Body Balance & The ability to maintain balance & Balance \\
\hline 9. Endurance & The ability to perform a prolonged effort & $\begin{array}{l}\text { Running and marching } 600 \\
\text { yards (550m) }\end{array}$ \\
\hline
\end{tabular}

\section{The Test Subjects.}

During a year of sportive training we monitored a test group of 16 children aged 7-10 years from a group of beginners swimmers of CSS no.1 in Bucharest. The criteria for choosing them were the following: health status, training frequency, work discipline, motivation for movement, good school results, and parental consent.

Initial and final tests were established and the results obtained were recorded. The level of endurance was the same for each training lesson. Children were close together in age.

5. Data collection and systematization of exercises

We found that working with children at this level, studies are interesting with surprising results. Four representative events were established. We chose as a study period a competitional year to track the evolution of these children over time and wether the practice can confirm the theoretical allegations in this field.

We mainly monitored the evolution of motor skills torought the whole school year and five training lessons lasting 120-150 minutes were performed weekly. In each semester, we undertook mandatory medical check-up, and we obtained useful information about the physiological level at that moment. Getting somatic data was useful to track their nutritional status and its changes. Rigorous planning were set up to meet the requirements of programs, standards and levels for children in this category.
Although we could not fit into all volume and especially intensity parameters, the effort level was reached by $70-80 \%$.

The tools used in the training program for developing motor skills are as following: $>$ running $(\mathrm{km}): 20 \%$ slow running, $15 \%$ specific swimming exercises, 5\% recovery running, $10 \%$ cross running, $10 \%$ constant tempo running, $25 \%$ flat accelerated running, $10 \%$ varied tempo running, $5 \%$ hill accelerated running;

$>$ throws (no. of repetitions): $30 \%$ throwing an oina ball, $70 \%$ throwing a medicinal ball,

$>$ jumps (no. of repeats): $40 \%$ triple jump, 40\% hurdling, 20\% long jump;

$>$ mobility and flexibility (hours): 10\%, mobility and suppleness, 90\% other means,

$>$ force (no. of exercises): $10 \%$ push-ups, $45 \%$ abs exercises, $45 \%$ back exercises.

The first test was carried out on the four events in the first week of October. The last test took place in the last week of June of the 2016-2017 school year.

The requested anthropometric data was as follows:

- Height (cm)

-Body weight (kg). 
"Mircea cel Batran" Naval Academy Scientific Bulletin, Volume XX - 2017 - Issue 2

The journal is indexed in: PROQUEST / DOAJ / Crossref / EBSCOhost/ INDEX COPERNICUS/ OAJI / DRJI / JOURNAL INDEX I I2OR / SCIENCE LIBRARY INDEX / Google Scholar / Academic Keys I ROAD Open Access I Academic Resources / Scientific Indexing Services I SCIPIOI JIFACTOR

Table 2. Means used in the training program for developing motor skills (in percent)

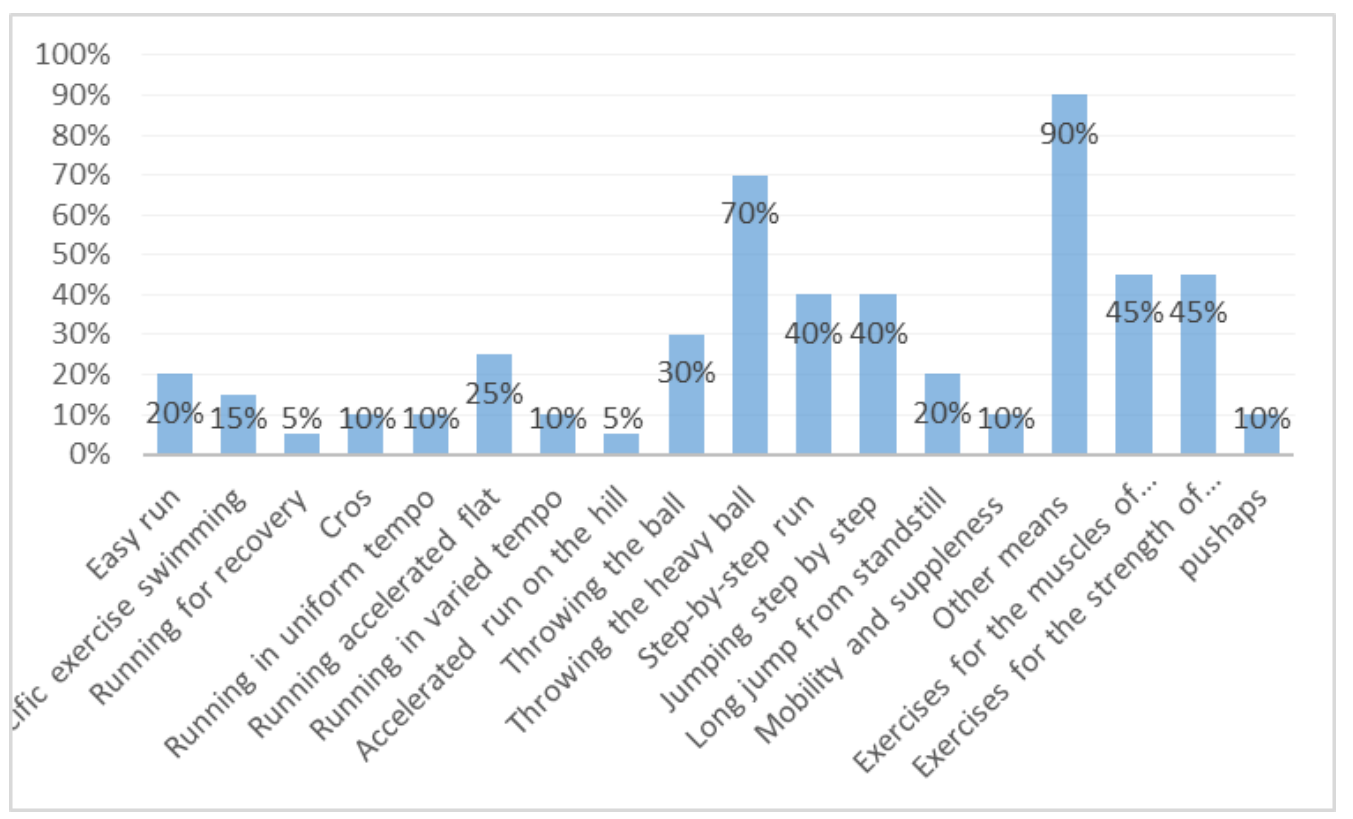

Table 3 Control samples

\begin{tabular}{|l|l|l|}
\hline Sample & Number of attempts & Determinant factor \\
\hline Run speeds 50m flat with start from legs & 2 tests & for the speed of travel \\
\hline Jumping in length, on the spot & 2 tests & for the explosive foot force \\
\hline Throwing the ball & 2 tests & $\begin{array}{l}\text { for the explosive force of the } \\
\text { arms }\end{array}$ \\
\hline Running $600 \mathrm{~m}$ & 1 test & for endurance \\
\hline
\end{tabular}

\section{Discussions on physical training in swimming events}

The Running school is part of physical training in all sports disciplines and resembles swimming because it has stereotyped technique and generally standardized competitions. Specific physical effort requires the athlete develop muscular strength, speed, resilience and metabolic processes related to the effort. Most swimming events particularly require 10 to 60 anaerobic period. Due to the type of muscular effort necessary in the training session or in the event, the coach chooses the events that morphologically fit in those activities, which require the muscle mass building and the skills to advanced or proficiently engage this force when most suited .

In planning the training program, the coach will use those force-speed means, but also means that track the elasticity and resistance of execution in the monostructured form (Metweyev, L., 1982). The coach proficiency is important and contributes to reaching the performance. Knowing that the objectives are to be built at the beginner athlete, the reflexes of adapting to the training stimuli, so that in the next stages through the overcompensation effects, to perform in one of the swimming events. Training hard and restoring, resuming the physical effort and its duration become guided mechanisms based on training principles and this requires study and focus from the coach, motivation and dedication from the athlete.

\section{Conclusion}

The end of the initiation and development period highlighted among the subjects a number of 6 athletes prone to achieving peak performance in swimming. Of these, one was particularly distinguished by proved to reach national quality performance.

The effects of physical effort adaptation have resulted in children's health and sports performance. The aims throughout the year of study consisted in obtaining superior indicators in general physical training. 
"Mircea cel Batran" Naval Academy Scientific Bulletin, Volume XX - 2017 - Issue 2

The journal is indexed in: PROQUEST / DOAJ / Crossref / EBSCOhost/ INDEX COPERNICUS/ OAJI / DRJI /

JOURNAL INDEX I I2OR / SCIENCE LIBRARY INDEX / Google Scholar / Academic Keys / ROAD Open Access I Academic Resources / Scientific Indexing Services / SCIPIOI JIFACTOR

\section{Bibliography}

[1]. Bompa, O., T., The Theory and Methodology of Training, pp.249-288, Ex Ponto CNFPA Bucharest, 2002.

[2]. Bowerman J. Willams, \& Freeman H. Williams (2006), Leisure Press - Champain, Illinois, 1991, The Basics of the Sport Training (page 52), Coach library, nr.2 ANS, INCS, Bucharest, 2006.

[3] Ene-Voiculescu, V., Ene-Voiculescu, C., Abramiuc, A., Current selection procedures in the naval pentathlon, "Mircea cel Batran" Naval Academy Scientific Bulletin, Volume XX, Issue 1, pp.420-422, 2017.

[4] Firea, E., The theory and methodology of school physical education, Ed.IEFS, 1988.

[5]. Fleischman, E., Examiner's Manual for the Basic Fitness Tests, 1964.

[6] Grimalschi, T., Modern Didactics of Physical Education, Guide for Teachers,Ed. Reclama, 2008.

[7] Matveyev, L., Fundamentals of Sports Training, Imported Pubn, 1982.

[8] Moldovan, M., The Right of Physical Education and Sport, Meteor Publishing, 2015.

[9]. Monea, G., Bondoc-Ionescu, D., Neamţu, M., Zanfirescu, M., Polyvalent and poly-athletic approach in children's training, Studia Journal, Universitatis Babeş-Bolyai, Educatio Artis Gymnasticae, Lv, 2, Pp.64-76, 2010.

[10] Prodea, C., Psychomotor / physical education; the methodology of their teaching in pre-school and primary education, Babes Bolyai University / Faculty of Psychology and Educational Sciences / course support, Cluj Napoca,2014.

[11] Stan, A.E.. Psychological effects of aquatic activity in hydrotherapy programs - Marathon Journal, indexate RePEc, A.S.E. Bucharest, vol. 5, nr. 2, A.S.E.Publishing, ISSN 2066-107X, 2013. http://www.marathon.ase.ro/pdf/vol5/2/14Stan.pdf

[12] Stan, A. E. Methodology of learning swimming in the first part of life through a positive approach. Annals of Ovidius University in Constanţa, Physical Education and Sports Series / Science, Movement and Health, ISSUE 1 - Volume XII, cat. B+, ISSN 1224-7358, Constanța; 2012.

http://www.analefefs.ro/anale-fefs/2012/issue-1/content.pdf

[13 Urichianu, A., Urichianu, B.A., Training of students on the ability and the habit of independent and systematic practice of exercise, objective and finality of physical education, International Conference of Social, Political and Human Sciences "Education, Research, Innovation in Knowledge Age", Titu Maiorescu University / Faculty of Social Sciences, Political and Humanistic Studies, 19-20 mai 2016.

14] Urichianu, B, Urichianu, A., Toma, S., Features of motion development in primary students, , Ecological University of Bucharest, Faculty of Physical Education and Sport, International Scientific Communications"Physical education and sport, healthy lifestyle boost factors" 08 aprilie 2016, ISSN 2360 1760, Ed printech, p.5-12; http://www.ueb.ro/efs/files/sesiuni_comunicari/EFS_2016.

[11] Urichianu Toma, S., Swimming in children, adolescents and young people, , Military technical publishing 2004. 